\section{CONNECTING THE DISCONNECTED: SOCIAL WORK AND SOCIAL NETWORK ANALYSIS. A METHODOLOGICAL APPROACH TO IDENTIFYING NETWORK PEER LEADERS}

\author{
Miguel del Fresno García \\ Universidad Nacional de Educación a Distancia (UNED) \\ mdelfresno@der.uned.es
}

\begin{abstract}
Citation/Cómo citar este artículo: Del Fresno García, M. (2015). "Connecting the Disconnected: Social Work and Social Network Analysis. A Methodological Approach to Identifying Network Peer Leaders". Arbor, 191 (771): a209. doi: http:// dx.doi.org/10.3989/arbor.2015.771n1011
\end{abstract}

Received: 16 enero 2014. Accepted: 25 julio 2014.
Copyright: $\odot 2015$ CSIC. This is an open-access article distributed under the terms of the Creative Commons Attribution-Non Commercial (by-nc) Spain 3.0 License.
ABSTRACT: Social network theory and analysis (SNA) offers a useful conceptual framework and a robust set of methods for understanding, analysing, and representing the pattern of social interactions that surround individuals forming an overall network of ties. SNA provides both insights and applications regarding relational structures that may be consequential for individual and collective agency. Despite the fact that both SNA and social work focus on relationships and behaviour, and that each discipline could substantively inform the other, there remains a significant lack of intersection between the two disciplines. In response to this gap, SNA applied to social work can provide additional ways to both diagnose and intervene behaviourally through the following approaches: a) by identifying key players in promoting the dissemination of behavioral changes in networks; b) by segmenting and identifying groups, cliques and communities; c) by supporting behavioural change through social ties surrounding the individual; and d) by aligning and applying specific interventions that draw on mutually interactive processes in terms of individual influences on networks, as well as network influences on individuals. SNA provides social work with an additional lens and set of tools based on the constellation of interactions surrounding individuals, families, groups or communities that supports understanding, diagnosis, and intervention.

KEYWORDS: Social Work; Social Network Analysis; SNA; positional inequality; situational inequality; peer leaders.
RESUMEN: La Teoría y Análisis de Redes Sociales (SNA) ofrece un conjunto de métodos de análisis de las interacciones sociales de los seres humanos, que permiten de forma específica investigar las estructuras relacionales y la representación de éstas como redes. SNA proporciona tanto acceso a nuevo conocimiento como la representación de las estructuras relacionales y como éstas pueden ser consecuencia de la acción individual y colectiva. A pesar de que tanto el SNA como el Trabajo Social tienen su foco en las relaciones y el comportamiento, de lo que ambas pueden beneficiarse, es significativa la falta de intersección entre ambas disciplinas. En respuesta a este déficit, el SNA puede ser aplicado al Trabajo Social desde los siguientes enfoques: a) la identificación de individuos claves a la hora de promover la difusión de cambios de comportamiento en redes; b) la segmentación e identificación de grupos, cliques y comunidades; c) el cambio de comportamientos a través de los miembros de la red y no del trabajador social como agente de cambio central; $y$ d) que la intervención orientada al cambio de comportamientos puede ser bidireccional: individuos-red y redindividuos. El SNA aporta al Trabajo Social la base estructuralrelacional para trabajar con individuos, grupos, familias o comunidades basados en patrones de interacción social, traduciendo los conceptos de las Ciencias Sociales y del Trabajo Social al servicio del diagnóstico y la intervención en red.

PALABRAS CLAVE: Trabajo Social; Análisis de Redes Sociales; SNA; desigualdad posicional; desigualdad situacional; líderes de opinión; intervención en red. 


\section{INTRODUCTION}

For the International Federation of Social Workers (ifsw.org), social work, in its various forms, addresses the multiple and complex relationships between people and their environment. Its mission is "to enable all people to develop their full potential, enrich their lives, and prevent dysfunction" (IFSW, 2013), for which theories on human behavior and social systems are used as conceptual tools in diagnosis and social intervention. Social work can be described as a professional activity that aims to help individuals, groups or communities to enhance or restore their social skills by understanding relationships with others and with their context. Thus, social workers "are change agents in society and in the lives of the individuals, families and communities they serve. Social work is an interrelated system of values, theory and practice" (IFSW, 2013).

The transition from an industrial society to an information society has had a significant impact upon social work. The benefits gained from such a transition have included simplified recording and assessment, electronic advocacy, interactive education opportunities and online group work and supervision (Csiernik et al., 2006). The social changes resulting from technological innovation have modified the structure of interpersonal relationships. Technology has also changed social work practice by offering new ways to perform services and obtain information. As the National Association of Social Workers and the Association of Social Work Boards confirm: "the challenges that it brings require a special set of skills and knowledge to provide the best practice available [...] these current and near-future technologies are changing the nature of professional social work practice in countless ways" (NASW and ASWB, 2005, p. 4).

The expanded social context of the Internet and social media has given rise to social networks on any number of topics and social behaviors. Unlike the mass media, which is a professional communicator, social media is a collective and interpersonal communicator. This has enabled the creation of a social interaction continuum, where offline and online social interactions are individually and collectively experienced (del Fresno, 2011a). Each wave of technology not only modifies the interpersonal relationships of large social groups, but also deepens or creates new and potential processes of social exclusion that can be studied with methodological approaches from other experimental science fields, such as social network analysis (SNA) to maintain and improve the quality of services provided by social workers.
As societies evolve and technology comes to form a growing part of processes of change related to ever more aspects of human activity, social work has incorporated new analytical approaches and new methodologies that enhance its capacity for comprehension and intervention, as we have done in recent years in the Konionia research group of the UNED (del Fresno and Lopez, 2012; del Fresno, 2011b). In this paper, we present the first findings of the intersection between online SNA and social work as a continuation of research in the field of healthcare social work on the use of and access to generic drugs in Spain and their relationship to universal access to healthcare (del Fresno and Lopez, 2014). In subsequent publications we will present ongoing research on SNA applied to social work and prostitution.

\section{SOCIAL WORK AND SOCIAL NETWORK ANALYSIS}

Social network analysis (SNA) was originally developed by Alfred R. Radcliffe-Brown to address the need to identify social structures as an evolution from Emile Durkheim's functionalist theory towards structural functionalism. For four decades (1930-1970), Radcliffe-Brown's metaphors of fabric and $w e b$ were prominent in the sociological understanding of social life as social network structures, and researchers began to investigate the density and texture of the social networks they studied. However, the most explicit and earliest structural approach to society dates back to Georg Simmel in the late nineteenth century, for whom "society exists where a number of individuals enter into interaction" (Simmel, 1972: 24) and the object of study of sociology "was no more and no less than the study of the patterning of interaction" (Freeman, 2004: 16). Simmel elaborated on this idea when he posited that "a collection of human beings does not become a society because each of them has an objectively determined or subjectively impelling life-content. It becomes a society only when the vitality of these contents attains the form of reciprocal influence; only when one individual has an effect, immediate or mediate, upon another, is mere spatial aggregation or temporal succession transformed into society. If, therefore, there is to be a science whose subject matter is society and nothing else, it must exclusively investigate these interactions, these kinds and forms of sociation" (Simmel, 1971, p. 25).

From 1930 to 1970 "an increasing number of social anthropologists and sociologists began to build on Radcliffe-Brown's concept of 'social structure' and, 
in doing so, began to take seriously the metaphors of the 'fabric' and 'web' of social life" (Scott, 2011, p. 4). From the 1970s onwards, there was "an avalanche of technical work and specialist applications appeared" (Scott, 2011 p. 5) from which the key theoretical concepts of SNA emerged. The sociogram - a graph drawing where individuals are represented as nodes and the relations between them as lines in a two-dimensional space (Figs. 1, 2, 3 and 4) was introduced as a tool of analysis by Jacob L. Moreno, who is considered the founder of modern SNA. The objective of the sociogram is "a way of representing the formal properties of social configurations" (Moreno, 1934/1953) which allows identifying both leaders and isolated individuals, as well as discovering asymmetric and reciprocal relations and creating maps of linked connections. One of the key concerns of Moreno was "the relationship between small-scale interpersonal configurations and large-scale social aggregates" (Scott, 2011, p. 9), thus summarizing some of the key ideas of Weber, Tönnies and Simmel, and anticipating the main sociometric issues of formal sociology.

SNA is based on the premise of the anti-categorical imperative (Emirbayer and Goodwin, 1994, p. 1414), which privileges relations over the categorical attributes of subjects to understand and explain individual or collective social processes. According to Linton C. Freeman (2000 and 2004), SNA involves four defining properties: a) it is motivated by a structural intuition of social relations; b) it is grounded in the systematic collection of empirical data; c) it relies on mathematical and computational tools to analyze and visualize such data; and d) it draws on graphic imagery to reveal the relationships and patterns of interactions, thus providing significant structural insights and explanations (Del Fresno, 2014).

Social work methodology relies on a system of knowledge based on evidence gained from research and assessment, including "local and indigenous knowledge specific to its context. It recognises the complexity of interactions between human beings and their environment, and the capacity of people both to be affected by and to alter the multiple influences" (IFWS, 2013). Social work with cases, families, groups or communities can benefit from SNA and the knowledge accumulated on ego-networks, small networks or large-scale networks and their applications to spheres as diverse as public health (Valente et al., 2003; Valente and Pumpuang, 2007; Valente, 2010), the acculturation processes of im- migrants (Maya-Jariego, 2006; Maya-Jariego and Armitage, 2007; Domínguez and Maya-Jariego, 2008) or in the community context (Zimmerman, 2000; Luke, 2005; Villasante, 2006; del Fresno, 2012; del Fresno, Daly and Supovitz, 2015). Despite the potential of SNA for social work as a significant body of knowledge, there is a significant lack of intersection between the two disciplines. Hence, linking SNA to the process of diagnosis, design and social intervention is both viable and pertinent. Five arguments justify the potential relationship between social work and SNA:

1. For both disciplines, social networks begin with people. The units of analysis are individuals or social entities (families, groups, communities, institutions, etc.) whose behavior must be described and explained through their relationships and edges.

2. Individuals and organizations that appear to act independently are, in fact, embedded in dense networks of relationships and wider social interactions. People weave dynamic networks of more or less dense relations that connect us more or less effectively with other individuals who, in turn, connect us with new individuals, groups and communities.

3. For SNA, social life is rooted in the structure of the positions and social relations and must be explained through the analysis of these patterns or distributions of positions, networks, and types of relationships. The most general feature of these relationships is that they are rooted in cultural and symbolic values that can be represented and analyzed due to their network structure. Thus, network models are constructed to reveal how these relationships influence attitudes and beliefs, and can explain human behavior.

4. The key is that from the structural standpoint, the patterns of ties in networks are both the cause and the effect of human behavior and as such there is constant feedback between structure and individual and collective behavior.

5. The need for professionals to cope with both traditional and new social problems of increasing levels of complexity and the rapid social changes occurring today, assuming that the emerging structures should resemble organic structures and therefore provide relevant information for decision making. 


\section{TYPES OF NETWORKS FOR SOCIAL WORK}

The first step in using SNA methodology in social work is to define the network under study. Because the term 'network' is a very graphic metaphor which conjures up images of nodes (individuals) connected by lines (relations), SNA studies social phenomena and their representation in the form of relational networks. This might appear to be no different from other forms of empirical research except that SNA studies "social phenomena by means of network representations [...] What is distinct in network analysis, however, are the kinds of data and methods, and the reasoning that motivates network representations and justifies the interpretation of results" (Henning et al., 2013, p. 15).

A social network consists of a finite number of a group or groups of actors (individuals, families, groups, organizations, communities, etc.) considered as interdependent units that have a relation or relations that define them and can be represented by a graph. The basic unit of analysis in SNA are dyads. A dyad is formed by a pair of actors (nodes) and a variable used to explain the tie (relation). The set of dyads between a certain number of individuals with the same type of property in the relation create a network. The dyads are extended to create triads, thus introducing the transitive analysis of relations. Subjects are deployed socially through multiple dyadic relationships among multiple actors that result in growing networks of relationships with identifiable patterns of interaction. Therefore no individual or collective actor can be considered conceptually as "social islands" (Flap, 2002).

Relational data contain contacts, links, connections, kinship relations, transactions, and services that are either rendered or received, which can be modeled to represent relationships between actors. The relations (affection, solidarity, disease, sex, money, fear, conflict, ideology, etc.) depend on the object of the network to be studied and "may be permanent or temporary, superficial or deep, regulated or informal, in course or consummated" (Lozares, 1996, p. 109) although it is necessary that the analysis focus on only one or some of these relationships. Unlike statistical approaches, the focus is not placed on the characteristics of the actors but the relations, structures and functions of the interpersonal and group networks which are described and analyzed.

The position that an individual occupies as a member of different social networks influences many aspects that demonstrate the possibilities and con- straints of a social structure on individual action and differential opportunities for access to knowledge, health, social capital and others. The intersection between social work and SNA allows explaining the behavior of the subjects according to their positions in the individual, family, group or community network structure. The relationships that can be studied depend on the research question, however, there are two key analytical alternatives on how a network is understood as a variable:

1. The network as a dependent variable: How and why do individuals interact with each other in a certain observed way? That is, to show and explain why people are related in a certain way. The explanation of social ties is often the aim of such research.

2. The network as an independent variable: What are the consequences of the relational structure that is identified? For example, the spreading of rumors or dysfunctional behaviors related to health. In short, how the network structure influences the action or behavior of its elements.

\subsection{Complete networks or open system networks}

Complete networks are used to investigate a particular type of relationship between all members of a unit of analysis. The complete network is defined by the relationships that all members of the network have with each other. However, if the network to be investigated lacks clear boundaries - which are the most interesting networks in some cases - sampling may be necessary. Moreover, the dynamic nature of networks often makes it necessary to delimit the study in time. In social work, the feasibility of examining the complete network or not will depend on how the unit of diagnosis and intervention is defined.

\subsection{Ego-centered networks}

To understand individual behavior it is necessary to understand local social structures, which is the goal of the analysis of ego-centered networks. An ego is an individual focal node whose direct network of direct relations with other individuals and the direct relations between these sets forms an ego-centered network. A network has as many egos as it has nodes. An ego can be persons, groups, organizations, a community, or whole societies. In terms of social work, ego-centered networks are a useful tool for cases, families and groups. 


\subsection{Socio-centric networks}

Socio-centric networks are networks in a box. These are the networks with which J. Moreno began his studies, where the network is understood as a closed and limited system. The research question will determine the definition of the network at a scale accessible to the researcher. In the field of social work, a socio-centric approach can be used for cases, families or communities; hence a socio-centric network or a network in a box could be sexual practices associated with risk behaviors among a certain group of teenagers or practices to incite or initiate teenagers in a high school class in the use of drugs.

\subsection{Scale-free networks}

Albert-Lászlo Barabasi and Réka Albert (1999) showed how large-scale social networks -which most resemble real social networks - do not follow random patterns but a preferential attachment distribution. Thus, large networks of scale-free power law show that 1) networks expand continuously by the addition of new nodes; and 2) that new nodes bind preferentially to nodes that are already connected. This demonstrated that large-scale networks tend to show a very significant phenomenon of self-organization beyond individual systems. The structure of largescale networks is therefore expected to present a high concentration of relations (edges) in a few individuals (nodes); a phenomenon that is applicable to a network of sexual contacts, organized crime, the nervous system, community leaders, etc.

\section{IDENTIFYING OPINION LEADERS TO PROMOTE CHANGE}

A basic starting point of any intervention project in the field of social work is to analyze the behavioral patterns of users, their survival strategies and their socio-cultural environment. As a helping profession, the goal of social work is to provide expertise knowledge in order to improve the skills of people, groups and communities so that they can pursue opportunities and cope with problems more successfully (del Fresno and López, 2014; del Fresno, Daly and Supovitz, 2015). To achieve these objectives, it is necessary to identify opinion leaders, the balance and distribution of power, and formal and informal leadership within groups, communities, etc. to promote changes in socially dysfunctional behavior. The advantage to this is that certain opinion leaders can act as agents to accelerate intervention processes without depending exclusively on social workers.
Opinion leaders tend to be identified as nodes for the diffusion of new ideas or behaviors (Rogers, 2003) based on the premise that once they have been properly identified, they may act as change agents by removing barriers and increasing the rate of acceptability of new ideas or behaviors (see, for example, Kelly et al., 1991; Lomas et al., 1991; Perry et al., 1986; Valente and Davis, 1999; Valente et al. 2003; del Fresno, Daly and Supovitz, 2015; del Fresno and Daly, 2015). It is also possible to identify key nodes (people) in a network to prevent the diffusion of erroneous or dysfunctional ideas, beliefs or behaviors (Stauffer and Aharony, 1991; Borgatti, 2006). Network models are used to solve various problems such as understanding resistance networks, forest fires, epidemics, biological evolution and social influence (Solomon et al., 2000) or public health (Valente et al. 2003; Valente and Pumpuang 2007; Valente, 2010). SNA has been used for the structural measurement of social capital in networks (see, for example, Coleman, 1990; Burt, 1992; Borgatti, Jones and Everett, 1998) where research pursues the opposite objective that is which network properties contribute to the existence of opinion leaders.

SNA is an analytical tool of great potential for social work as social workers tend to use the non-sociometric methods of the positional approach. Thus, social work could incorporate the sociometric methods of SNA to identify opinion leaders (Valente and Pumpuang, 2007). What diagnostic and intervention teams generally do is to identify opinion leaders based on the organizational position they occupy within the group or community. Examples of this type of leaders include elected officials, religious leaders, community organizers, prestigious people, etc. It is a relatively simple process of identifying formal opinion leaders as those who have more power in relation to legal, political or ideational aspects based on their organizational hierarchy. However, this method has three disadvantages:

a) social workers who are responsible for diagnosis and intervention may identify these opinion leaders in an erroneous manner;

b) formal leaders may not be perceived as peer leaders by the group or community and lack any real influence in practice; and

c) these leaders may be ambivalent or hostile to an innovation or behavior change (Locock et al., 2001) promoted by social workers. 
It is therefore necessary to supplement this method with others that can aid in identifying informal opinion leaders or peer leaders within the group or community. For this purpose, SNA is presented as a conceptual sociometric tool. Valente and Pumpuang $(2007$, p. 886$)$ described three methods that use SNA:

1. Snowball Method. A randomly selected sample of members of a group or community are asked to nominate opinion leaders of their group or community, thus identifying the initial leaders. In a second round, interviews are held again and the process is repeated until an identification threshold is established and a sufficient number of peer opinion leaders have been identified. The advantages to this method are that the data are representative and generalizable and the collection of data can be adjusted and modified during the process until a sufficient number of opinion leaders have been identified. The disadvantages lie in both the representativeness of the sample and the fact that if the group or community is large, the field work required to locate and interview the individuals may be time-consuming.

2. Sample Sociometric. A representative sample of members of a group or community are asked to nominate opinion leaders of their group or community. A threshold is established to identify the peer opinion leaders. Unlike the above method, in this method it is assumed that the group or community to be diagnosed or intervened is clearly delimited. Specifically, the selected sample should comprise $50 \%-80 \%$ of all the members of the group or community to ensure a sufficient confidence level (Costenbader and Valente, 2003) to identify the peer opinion leaders. The disadvantages again lie in the representativeness of the sample and the need for a clearly delimited study group (i.e., a school, a neighborhood, an organization, etc.).

3. Sociometric Method. This method may have the highest validity and reliability for identifying peer opinion leaders. All or most members of the group or community are interviewed and a matrix is constructed with the data of all the nominations. The advantage to this method is that the entire network can be mapped in a graph and other classic metrics of centrality related to the position that the individuals occupy can be used to identify network leaders (Freeman, 1979). Thus, this type of opinion leaders are identified according to their centrality in the network of their social group, and are nominated by their colleagues or peers with whom they have regular contact and close relations, as well as being respected for their opinions (Buller et al., 2000, p. 233). A disadvantage is that the method may be time-consuming and expensive if it is large and unfeasible for networks of 1000 members or more. This limitation can be overcome by using online questionnaires (Daly, 2010; Daly et al., 2014) or by tracking and extracting the relations in an online relational context (del Fresno, 2011a, 2011b) of a group or community.

\subsection{Centrality measures: Degree and Betweenness}

The concept of centrality in SNA addresses the question of which are the most important or central nodes in a network (Newman, 2010, p. 168), that is, it identifies individuals that are structurally important and, more generally, the relative importance of all the individuals in the network. From this point of view, centrality measures assign values from highest to lowest, are an index at the individual level, and provides numerous metrics that allow identifying key individuals according to the objectives of the analysis.

Degree and betweenness are the key measures of centrality. Degree is a very simple but highly enlightening metric that measures the number of edges connected to a node. In SNA, a high degree indicates a large number of connections; hence, people who have connections with many others have more influence, more access to information, or more prestige than those with fewer connections (Newman, 2010: 169). In this regard, the degree of centrality can be regarded as an indicator closely associated with accelerated diffusion (Valente, 2010, p. 97). The degree of a node is calculated as the sum of the incoming degree or in-degree and the outgoing degree or out-degree. The in-degree is the number of edges coming into the node, while the out-degree is the number of edges originating from the node and going outward to other nodes (Golbeck, 2013, p. 40).

Identifying people, media, groups, etc. - which, as nodes, function as a bridge or connection between 
different networks on the major paths of a network where news, information, perceptions, rumors or falsehoods circulate - is a critical factor in any group or community. The idea of mediation is captured with the betweenness centrality measure, since it indicates how often a given node is on the shortest path between two other nodes, which can be considered as a gate-keeping value. Nodes with high betweenness may have considerable influence within a network as they control the information passing between some nodes and others (Newman, 2013, p. 186). On the other hand, when nodes with high betweenness are eliminated, they disrupt the relationship between other nodes as they are in the center of a large number of possible paths along which the properties of the relationships circulate (Newman, 2013, p. 18; Everton, 2011).

We present a theoretical model developed prior to the fieldwork to identify and analyze the relationships and network structure of a group of prostitutes (women prostitutes, transsexual prostitutes, etc.) and the individuals or entities associated with the reference group (NGOs, social organizations, religious organizations, social workers, social service assistants, health professionals, family members, clients, etc.) and involved in providing different forms of support (physical, emotional, economic, health related, etc.)

Figure 1. Degree of the individuals in a network

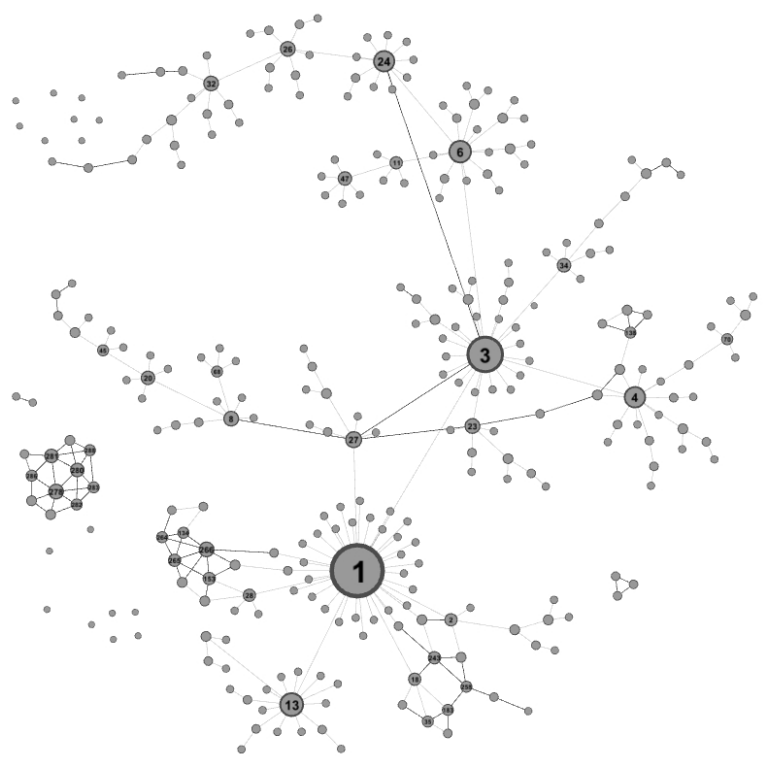

Source: the author. demanded by the reference group. They represent all the nominations as peer opinion leaders $(n=294$ nodes and 314 relations) in response to the question "Who do you go to when you need X support?" which can be answered in an open and unrestricted manner. The network representation permits identifying the importance of each node according to the relationship it has with other members of the network and their position in it. Using degree and betweenness metrics, two different networks based on the nominations of peer opinion leaders are presented for all the forms of support. The networks will also disaggregated by type of support.

The network analyzed according to the degree of each node (Fig. 1) reveals that nodes 1, 3, 13, 6, 24, 27, 8 and 266 are the most popular peer opinion leaders or individuals. In the network that analyzes and represents the network in terms of betweenness (Fig. 2), nodes 3, 1, 6, 24, 27, 26, 4, 8 and 13 are the peer opinion leaders or individuals who make bridges between different networks within the group or community. Depending on the goals pursued by the intervention in the group or community, certain peer opinion leaders are selected. This network structure permits establishing priorities and identifying critical issues in the diagnostic stage prior to intervention by social workers.

Figure 2. Betweenness of the individuals in a network

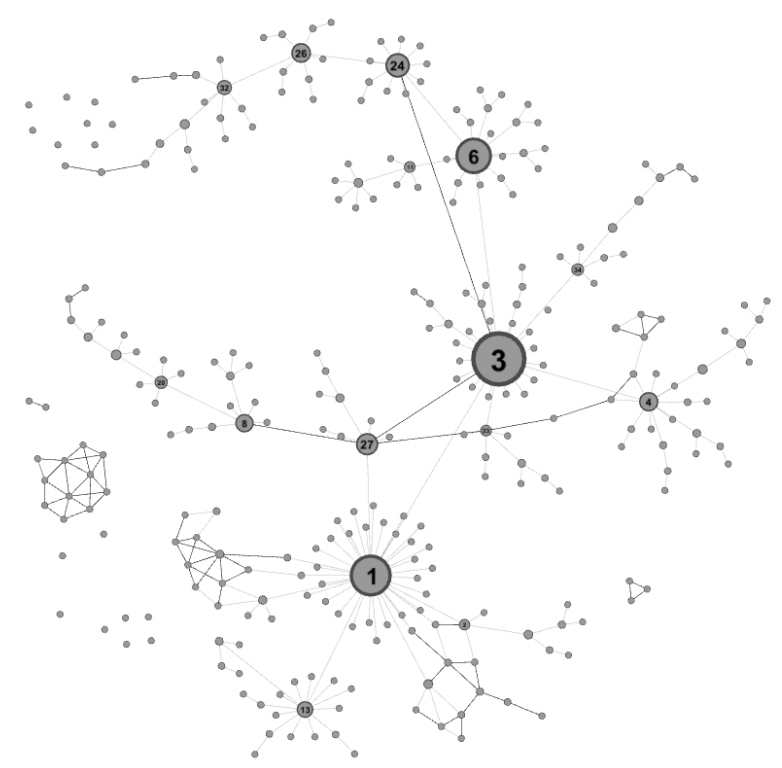

Source: the author. 
The network also reveals the existence of isolated individuals (nodes without links with other nodes on the left side of the graphs or isolated dyadic relations); individuals with very few edges on the periphery of the network whose link with the network is very weak as the nodes will be isolated if they lose one or two edges; multiple ego-networks that indicate the strength or weakness of an individual's connections to the network and their degree of centrality or risk of becoming disconnected; small communities or clique that are densely related but isolated from the main network (middle left of the graph), etc. SNA is therefore not only a theoretical method but a powerful tool for analysis and representation that can be used by social workers in the field before and after diagnosis and intervention in a group or community to determine formal relations in networks, the importance of certain nodes, and the possibilities SNA offers as a predictor of the risk of exclusion.

\subsection{SNA and the hospital pharmaceutical co-payment scheme in Spain}

Given the global financial crisis that began in early 2008 "that [is] driving Europe into a spiral of everdeepening recession [...] it is not surprising that the responses have been badly flawed, and in some cases have exacerbated the problems" (Stiglitz, 2012). In Spain, the government of the People's Party, which has held absolute majority since November 2011, requested financial intervention from the $\mathrm{EU}$ in June 2012 to tackle the debt crisis and prevent the collapse of the Spanish banking system. At the same time, the government has implemented austerity and liberalization measures that are having an enormous impact on all spheres of society, especially in health, education and social services. These decisions have led to the "weakening of social policies and rights that had put all citizens on an equal standing and played a key role in the redistribution of wealth (health, aid and social benefits)" (Caritas Española, 2013, p. 3).

The public health system is undergoing a process of privatization and liberalization which threatens to turn what has always been a right in Spain into a market product: healthcare. This wave of austerity measures has lead to significant changes in the healthcare system and coverage and has had a direct impact on citizens in a number of ways, namely: a) increased out-of-pocket expenditure on prescription drugs, b) poorer access to medical care, c) abandonment of care, and d) fear and stress among illegal immigrants (Caritas Española, 2013, p. 4). On October 1,
2013 a prescription drug co-payment scheme came into force in Spain, which requires that patients pay $10 \%$ of the price of medicines that are dispensed by hospital pharmacies. This measure includes drugs prescribed for chronic or serious conditions such as several types of cancer, HIV or hepatitis C, which require medical supervision and which, until now, were exempt from payment.

The academic world has long recognized the potential of SNA for conducting research on the Internet (Rogers, 1987; Watts, 2007). Social media are online technology platforms targeted at synchronous and asynchronous human interaction with a global and local reach unprecedented in human history. The Internet and Internet architecture have enabled the development and use of these platforms to support personal interactions, thus giving rise to a complex interaction between social practices and technology infrastructure. Indeed, we live in a complex labyrinth of networks with edges that link people who share information, ideas, perceptions, beliefs, myths, rumors, etc. in a real-time, immense, networked communication system (del Fresno and Daly, 2015). The result is that, today, everything is connected: people, information, events and places; all of which build relationships with each other to form a vast aggregate social network. Twitter is an online social platform that is evolving to become a media of intersection of every media and medium. The most significant aspect of Twitter for SNA is that it allows the exchange of mass and interpersonal communication features to understand the structure of information diffusion networks on a scale that was unimaginable just a decade ago.

Over a period of 24 hours (from 9: 00 am on 4 October 2013 to 9: 00 am on 5 October 2013), we retrieved all the publications on Twitter containing the keyword copago (co-payment). Following the approval of the Royal Decree to implement the co-payment scheme in hospitals, the online climate of opinion focused on the effects and consequences of the scheme on chronic patients. The retrieved data was then organized to obtain a network representation for the purpose of identifying opinion leaders (individuals, NGOs, journalists, digital media and online media communication professionals) using the in-degree algorithm. The network comprised 1,949 nodes (individuals) and 2,293 relationships (Fig. 3). In a second phase of analysis, the giant component, or the network with the highest number of interconnected nodes (Fig. 4) was extracted. The analysis of the network permitted us to identify opinion leaders (the largest nodes) and 
revealed the predominance two online media, several patient organizations, one very prominent journalist, and social movements participating in the climate of opinion regarding the hospital copayment scheme. This same method can be used for longer periods of study and applied to groups and communities of different scopes, or topics that are the object of investigation and intervention in the field of social work.

This analysis is an scientific, economic, and resultsoriented analytical approach to identify opinion leaders without the need for excessive computational capacity or large investments. The methodology is based on pattern recognition and the straightforward identification of hidden signals within social networks based on the exchange of information regarding social work subjects. In order to maximize its efficiency, reassessments and the reidentification of opinion leaders is critical.

The key for social work practitioners lies not only in the identification of opinion leaders, but also in defining the ideal information mix to input into social networks with the aim of reaching a "tipping point" (Schelling, 1978; Gladwell, 2000) that allows optimal diffusion at the desired level. This suggests the importance of gaining a deeper understanding and identifying network opinion leaders in the movement of resources related directly to social work interventions.

Figure 3. Co-payment: In-degree and full network

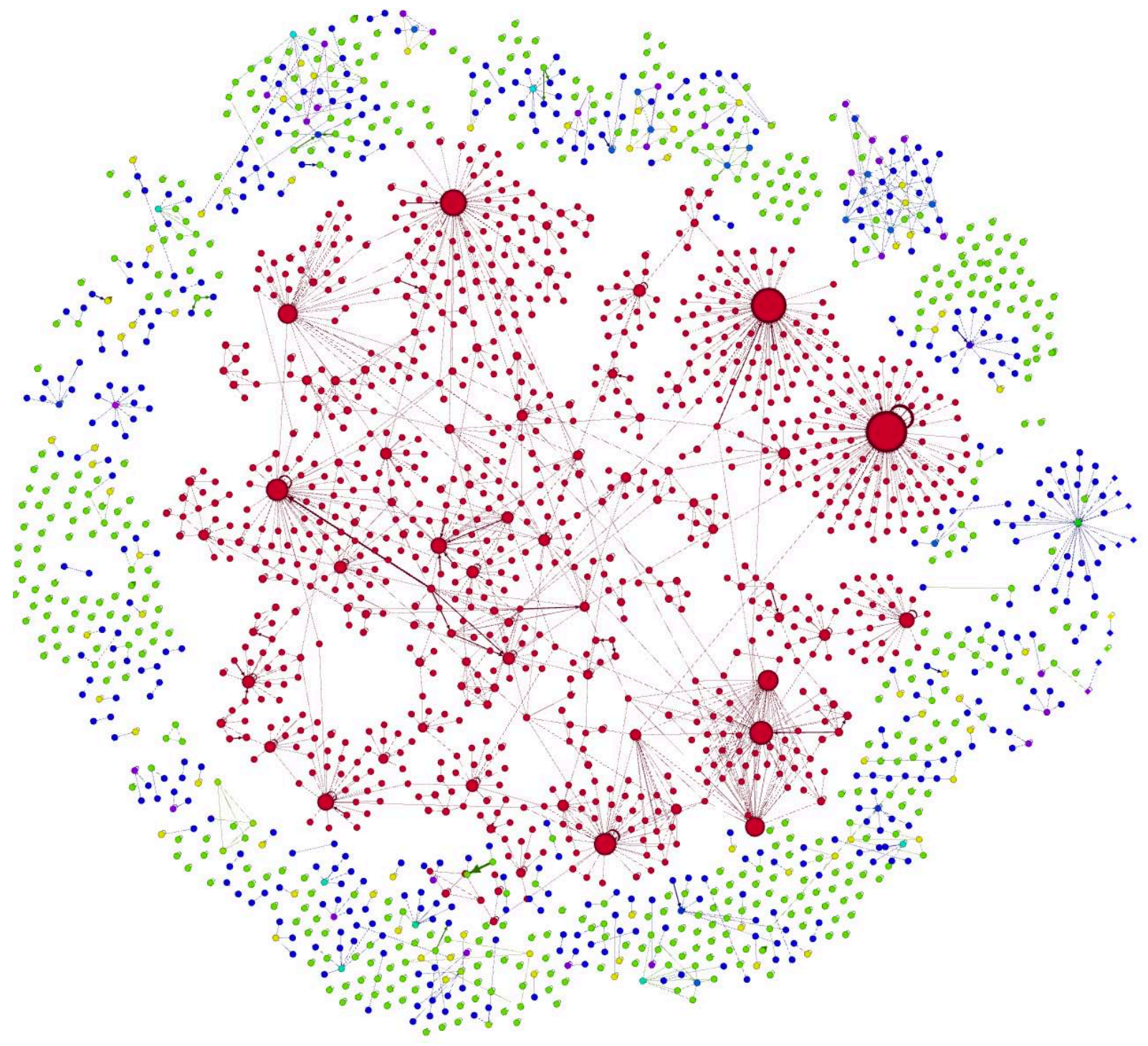


Figure 4. Co-payment: In-degree and giant component

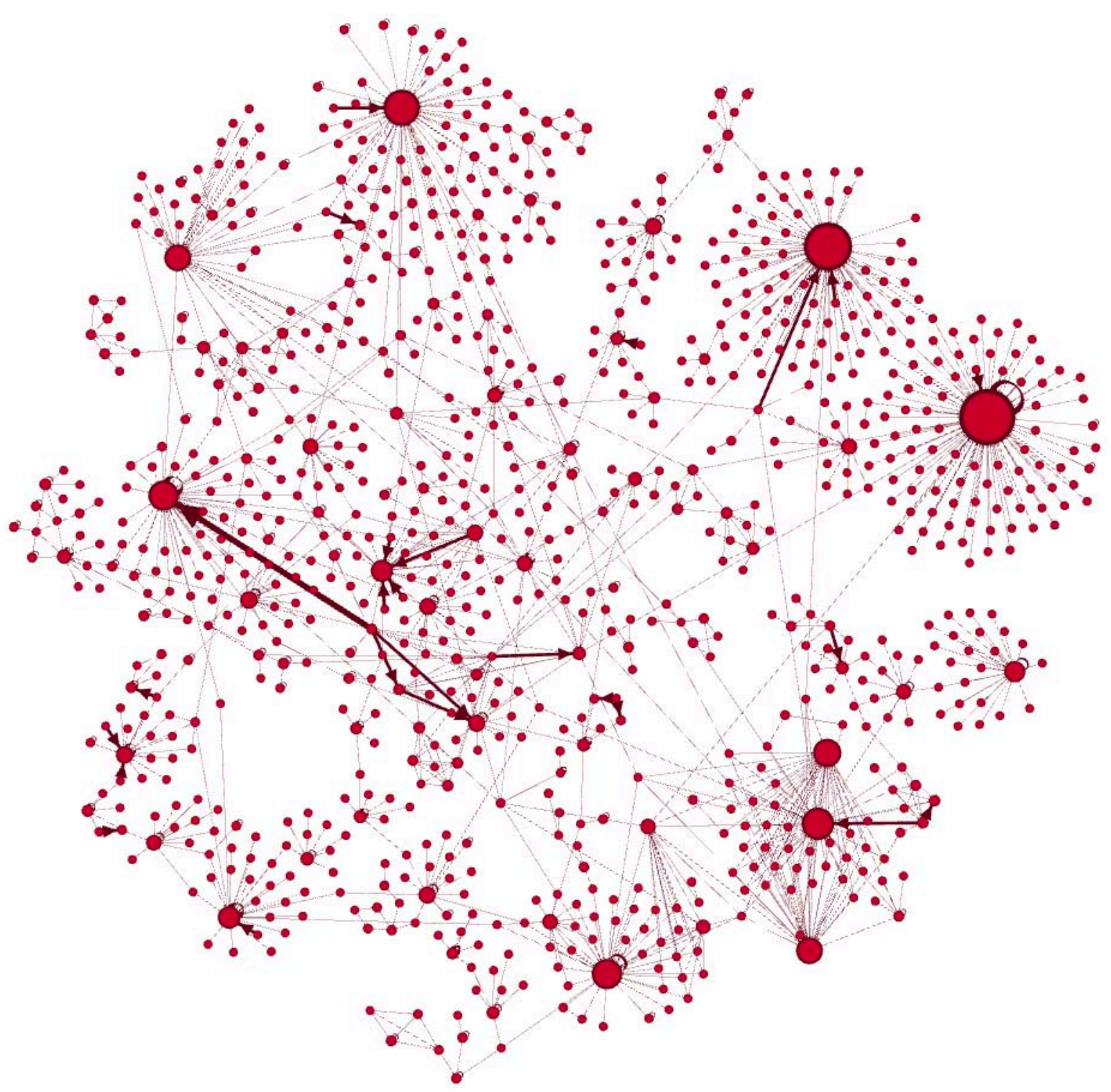

\section{SNA AND NEW FORMS OF INEQUALITY}

Online SNA also provides a new approach for analyzing social stratification and hierarchy as it reveals how individuals are positioned with respect to their edges (Fig. 3). Thus, SNA permits addressing the concept of social inequality from an additional perspective. Social work and other social sciences have typically addressed the issue of inequality as a situational category, that is, inequality caused by differences in income, social class, ethnicity or caste, gender, geographic origin, educational level, access to health, age, political participation, etc. and their correlations
(Bourdieu, 1986; Pakulski, and Waters, 1996; Coburn, 2004; Abel, 2008; Lazarato, 2009; Ortiz and Cummings, 2011; Mandel, 2012; Stiglitz, 2012; Weeden and Grusky, 2012). In contrast to this situational approach, SNA permits addressing another type of inequality: positional inequality resulting from the position that individuals occupy in their social networks.

It is evident in our everyday social reality that some people have more connections and others less, that some people are in positions of centrality while others remain on the periphery of groups and communities, and that some have easier access to resources, 
emotional support and jobs than others depending on their position in the different networks to which they belong. In a world with growing levels of interconnectivity, "in fact, the tendency of people with many connections to be connected to other people with many connections distinguishes social networks from neural, metabolic, mechanical, or other nonhuman networks. And the reverse holds true as well: those who are poorly connected usually have friends and family who are themselves disconnected from the larger network" (Christakis and Fowler, 2009, p. 301). As a result, those who occupy prominent positions in social networks tend to benefit more from network interactions as Barabasi and Réka Albert (1999) show in the study on free-scale networks, the most common in the social reality. Hence, in an increasingly interconnected world, positional inequality feedbacks into situational inequality.

The idea of positional inequality can be linked to the social capital theory of Coleman, since for Coleman the value of social capital resides and is embedded in the relationships between individuals and defined by their function (Coleman, 1988, 1990). Thus, the "function identified by the concept of social capital is the value of these aspects of social structure to actors as resources that they can use to achieve their interests" (Coleman, 1988, p. 101). Social capital is therefore understood as a property of the groups or institutions to which people have access, as all investment in social ties produces a stock of resources that people can use later to achieve their goals. For Bourdieu, social capital emerges as "the aggregate of the actual or potential resources which are linked to possession of a durable network of more or less institutionalized relationships of mutual acquaintance or recognition" (Bourdieu, 1986, p. 248) or as "'the sum of the resources, actual or virtual, that accrue to an individual or a group by virtue of possessing a durable network of more or less institutionalized relationships of mutual acquaintance and recognition' (Bourdieu and Wacquant, 1992, p. 119). These positions are consistent with SNA insofar as the greater number of social interactions and relationships one has, the more capital one has and the more likely one is to have higher chances of success in the social deployment of individuals, groups and communities.

From another point of view, Robert Putnam (1995), who tied in with the tradition of Tocqueville, understands social capital as being proper of broader groups such as a country, where membership in associations and social relations increase the civic values and the collective social good. For Putnam, social capital is an attribute that permeates the culture of political systems and even entire nations. Most importantly, social capital resides in societies, and is similarly accessible to all citizens and not only the most capable of establishing social connection networks (Furstenberg and Kaplan, 2004, p. 220). Undoubtedly, this is applicable to SNA, although it is beyond the natural scope of social work as it can expand or abstract the subject of intervention to too great of an extent.

\section{CONCLUSIONS}

Following the advent of the Internet in the 1990s, the social changes associated with information technologies have occurred at a rapid pace and had an enormous impact on the social sciences and social work practice. As a result, "the roles for social workers are changing and they may need to adjust to the new demands for practice in the information age. Social workers should acquire adequate skills that use technology appropriately, and adapt traditional practice protocols to ensure competent and ethical practice" (NASW and ASWB, 2005, p. 6). Netnography (del Fresno, 2011b, 2012; del Fresno and López 2012, 2014) and social network analysis have now become new fields of enquiry for social work as a helping profession that aims to provide expert knowledge in order to improve people's skills so that they can pursue opportunities, cope with problems more successfully and assess users' environments with a view to designing social intervention programs.

We live in a complex labyrinth of networks with connections that link people who share information, ideas, perceptions, beliefs, myths, rumors, etc. in a real-time, immense, networked communication system. Thanks to SNA, social workers now have conceptual tools from the experimental sciences for performing diagnoses and more competent and effective interventions. SNA is an analytical tool with a twofold potential: a) to identify opinion leaders directly in the field during the diagnostic phase, and b) as an innovation in the context of the online social networks of these opinion leaders and the diffusion of functional or dysfunctional practices and beliefs among society. Regardless of the object of study, SNA permits social workers to materialize the invisible: the relationships and ties in groups and communities of medium or high complexity. Moreover, it allows identifying those individuals or groups who, due to their position in networks, play formal or informal roles as opinion leaders that influence the perceptions and opinions of other members of the network. 
In a society where interconnection is growing and multiple, the result is that today everything is connected: people, information, events, and places; all of which build relationships with each other to form a vast aggregate social network. The SNA provides a form of analytical understanding of the phenomenon of inequality. The connections that people have and those they have with other people (positional inequality) may be as important as the other indicators of inequality arising from socio-economic status, education or health, race, sex, etc . (situational inequality). Positional inequality occurs not as a result of who we are, but who we are connected to (Christakis and Fowler, 2009, p. 300), and is a new indicator and predictor of social exclusion. The new risks of social exclusion arising from positional inequality pose a new challenge for social workers: to connect or reconnect the disconnected to their natural networks of belonging, whether they be individuals, groups, families or communities at risk of being disconnected from the major networks of which they form part. This has opened the way for network intervention (Valente, 2012) as an additional approach to the practice of social work as a helping profession.

Finally, SNA leads us to consider the preliminary issue of what strategies are most appropriate for each case and in each context of intervention, thus paving the path for exploring interventions in which assessments and diagnoses, alongside the process of participation in the network itself, are the basis of action. In short, SNA provides the structural-relational framework for understanding individuals, groups, families or communities based on patterns of social interaction between subject and context, thus translating the concepts of social sciences and social work to a new dimension that can inform assessment and intervention in a scientific manner.

\section{REFERENCES}

Abel, T. (2008). Cultural capital and social inequality in health. Journal of Epidemiology and Community Health, 62, 7, e13. http://dx.doi.org/10.1136/ jech.2007.066159

Barabási, A. L. and Albert, R. (1999). Emergence of Scaling in Random Networks. Science, 286, pp. 509-512. http://dx.doi. org/10.1126/science.286.5439.509

Borgatti, M. G., Jones, C. and Everett, M. G. (1998). Network measures of social capital. Connections, 21, 2, pp. 27-36.

Borgatti, S. P. (2006). Identifying set of key players in a social network. Computational Math Organization Theory, 12, pp. 21-34. http://dx.doi.org/10.1007/ s105880067084x

Bourdieu, P. (1986). The forms of capital. In Richardson, J. (ed.) Handbook of Theory and Research for the Sociology of Education. New York: Greenwood, pp. 241-258.

Bourdieu, P. and Wacquant, L. P. (1992). An Invitation to Reflexive sociology. Chicago: University of Chicago Press. http://dx.doi.org/10.1017/ S0829320100003380

Buller, D., Buller, M. K., Larkey, L., SennottMiller, L., Taren, D., Aickin, M., Wentzel, T. M. and Morrill, C. (2000). Implementing a 5-a-day peer health educator pro- gram for public sector labor and trades employees. Health Education \& Behavior, 27, 2, pp. 232-240. http://dx.doi. org/10.1177/109019810002700209

Burt, R. S. (1992). Structural Holes: The social structure of competition. Cambridge: Harvard University Press. http://dx.doi. org/10.1177/000169939403700410

Cáritas Española (2013). VIII Informe del Observatorio de la Realidad Social. Empobrecimiento y desigualdad social. El aumento de la fractura social en una sociedad vulnerable que se empobrece [on line] [Date accessed: 10 of November 2015]. Available from http://es.scribd.com/doc/175014689/ VIII-Informe-ORS-Ca\%CC\%81ritas-Octubre-2013

Christakis, N. A. and Fowler, J. H. (2009). Connected. New York: Back Bay Books.

Coburn, D. (2004). Beyond the income inequality hypothesis: class, neo-liberalism, and health inequalities. Social Science \& Medicine, 58, 1, pp. 41-56. http://dx.doi. org/10.1016/S02779536(03)00159X

Coleman, J. S. (1988). Social capital in the creation of human capital. American Journal of Sociology, 94, pp. 95-121. http://dx.doi.org/10.1086/228943

Coleman, J. S. (1990). Foundations of Social Theory. Cambridge: Belknap Press of
Harvard University Press. http://dx.doi. org/10.1177/000169939103400206

Costenbader, E. and Valente, T. W. (2003). The stability of centrality measures when networks are sampled. Social Networks, 25, pp. 283-307. http://dx.doi. org/10.1016/S03788733(03)000121

Csiernik, R., Furze, P., Dromgole, L. and Rishchynski, G. M. (2006). Information technology and social work- the dark side or the light side? Journal of Evidence-Based Social Work, 3, 3/4, pp. 9-25. http:// dx.doi.org/10.1300/J394v03n03_02

Daly, A. J. (2010). Surveying the Terrain Ahead: Social Network Theory and Educational Change. In Daly, A. J. (ed.) Social Network Theory and Educational Change. Cambridge: Harvard Education Press, pp. 259-274. http://dx.doi.org/10 $.1080 / 00220671.2011 .620794$

Daly, A. J., Liou, Y. Tran, N. Cornelissen, F. and Park, V. (2014). The Rise of Neurotics: Social Networks, Leadership, and Efficacy in District Reform. Educational Administration Quarterly, 50, 2, pp. 233-278. http:// dx.doi.org/10.1177/0013161X13492795

Del Fresno, M. (2011a). Infosociabilidad: Monitorización e Investigación en la web 2.0 para la toma de decisiones. El profesional de la información, 20, 5, pp. 548554. http://dx.doi.org/10.3145/epi.2011. sep.09 
Del Fresno, M. (2011b). Netnografía. Investigación, análisis e intervención social. Barcelona: Universitat Oberta de Catalunya.

Del Fresno, M. and Daly, A. J. (2015). Identifying social media influencers through social media network analysis. A study on Twitter. Public Relations Rewiew (In process of publication)

Del Fresno, M. (2012). Un nuevo ámbito: Trabajo Social Comunitario, Internet, redes sociales y capital social online. In del Fresno, M., Segado, S. y López, A. (eds.) Trabajo Social con Comunidades en el siglo XXI. Madrid: Universitas, pp. 149-199. http://dx.doi.org/10.5944/comunitania.6.6

Del Fresno, M. and López, A. (2012). Innovación, riesgo y sostenibilidad: la estrategia de deslegitimación social de los medicamentos genéricos. Sistema. Revista de Ciencias Sociales, 227, pp. 3-22.

Del Fresno, M. and López, A. (2014). Social work and Netnography: The case of Spain and generic drugs. Qualitative Social Work, 13, 1, pp. 85-107. http://dx.doi. org/10.1177/1473325013507736

Del Fresno, M. (2014) Haciendo visible lo invisible: Visualización de la estructura de las relaciones en red en Twitter por medio del Análisis de Redes Sociales. El profesional de la información, 23, 3, pp. 246-252. http://dx.doi.org/10.3145/ epi.2014.may.04

Del Fresno, M., Daly, A. J. and Supovitz, J. (2015). Desvelando climas de opinión por medio del Social Media Mining y Análisis de Redes Sociales en Twitter. El caso de los Common Core State Standards. Revista Redes. http://dx.doi. org/10.5565/rev/redes.531

Domínguez, S. and Maya-Jariego, I. (2008). Acculturation of host individuals: immigrants and personal networks. American Journal of Community Psychology, 42, pp. 309-327. http://dx.doi. org/10.1007/s1046400892095

Emirbayer, M. and Goodwin, J. (1994). Network analysis, culture, and the problem of agency. American Journal of Sociology, 99, pp. 1411-1454. http://dx.doi. org/10.1086/230450

Everton, S. F. (2011). Network Topography, Key Players and Terrorist Networks. Connections, 32, 1, pp. 12-19.

Freeman, L. C. (1979). Centrality in social networks: Conceptual clarification. Social
Networks, 1, pp. 215-239. http://dx.doi. org/10.1016/03788733(78)900217

Freeman, L. C. (2000). Visualizing social networks. Journal of Social Structure, 1, 1. Available from http://www.bebr. ufl.edu/files/Visualizing\%20social\%20 networks_0.pdf

Freeman, L. C. (2004). The development of social network analysis. A study in the sociology of science. Vancouver, BC: Empirical Press. http://dx.doi. org/10.1016/j.socnet.2004.01.008

Flap, H. D. (2002). No man is an island. In: Lazega, E. y Favereau, O. (eds.). Conventions and Structures. Oxford: Oxford University Press. http://dx.doi. org/10.4337/9781781952863.00007

Furstenberg, F. and Kaplan, S. (2004). Social capital and the family. In: Scott, J., Treas, J. and Richards, M. (eds.) The Blackwell companion to the sociology of families. Oxford: Blackwell Publishing, pp. 218-232. http://dx.doi. org/10.1002/9780470999004.ch13

Gladwell, M. (2000). The tipping point: How little thingscan makea big difference. New York: Stoddart Publishing. http://dx.doi. org/10.1080/15610950400010043

Golbeck, J. (2013). Analyzing the Social Web. Boston: Morgan Kaufmann. http://dx.doi.org/10.1016/ B9780124055315.00016X

Hennig, M., Brandes, U., Pfeffer, J. and Mergel, I. (2013). Studying Social Networks: A Guide to Empirical Research. Frankfurt am Main: Campus Verlag.

International Federation of Social Workers (IFSW) (2013). Global Definition of Social Work. [on line]. [Date accessed: 10 of November 2015] Available from http://ifsw.org/policies/definition-ofsocial-work/http://dx.doi.org/10.1093/ acrefore/9780199975839.013.202

Kelly, J. A., St. Lawrence, J. S., Diaz, Y. E., Stevenson, L. Y., Hauth, A. C. and Brasfield, T. L. (1991). HIV risk behavior reduction following intervention with key opinion leaders of population: An experimental analysis. American Journal of Public Health, 81, pp. 168-171. http://dx.doi. org/10.2105/AJPH.81.2.168

Lazzarato, M. (2009). Neoliberalism in Action: Inequality, Insecurity and the Reconstitution of the Social. Theory, Culture \& Society, 26, 6, pp. 109-133. http://dx.doi. org/10.1177/0263276409350283
Locock, L., Dopsonb, S., Chambersc, D. and Gabbayd, J. (2001). Understanding the role of opinion leaders in improving clinical effectiveness. Social Science \& Medicine, 53, 6, pp. 745-757. http://dx.doi. org/10.1016/S02779536(00)00387-7

Lomas, J., Enkin, M., Anderson, G. M., Hannah, W. J., Vayda, E. and Singer, J. (1991). Opinion leaders vs. audit feedback to implement practice guidelines: Delivery after previous caesarean section. Journal of the American Medical Association, 265, pp. 2202-2207. http:// dx.doi.org/10.1001/jama.265.17.2202

Lozares, C. (1996). La teoría de redes sociales. Papers, 48 , pp. 103-126

Luke, D. A. (2005). Getting the big picture in community science: Methods that capture context. American Journal of Community Psychology, 35, pp. 185-200. http://dx.doi.org/10.1007/ s104640053397z

Maya-Jariego, I. (2006). Webs of compatriots: Relationship networks among immigrants. In Pérez, J. L. (ed.) Geografías del desorden. Migración, alteridad y nueva esfera social. Valencia: Universidad de Valencia, pp. 257-276.

Maya-Jariego, I. and Armitage, N. (2007). Multiple senses of community in migration and commuting. The interplay between time, space and relations. International Sociology, 22, 6, pp. 743-766. http://dx.doi. org/10.1177/0268580907082259

Mandel, H. (2012). Winners and Losers: The Consequences of Welfare State Policies for Gender Wage Inequality. European Sociological Review, 28, pp. 241-262. http://dx.doi.org/10.1093/esr/jcq061

Ministerio de Sanidad, Servicios Sociales e Igualdad (2013). Resolución de 10 de septiembre de 2013, de la Dirección General de Cartera Básica de Servicios del Sistema Nacional de Salud y Farmacia, por la que se procede a modificar las condiciones de financiación de medicamentos incluidos en la prestación farmacéutica del Sistema Nacional de Salud mediante la asignación de aportación del usuario, Boletín Oficial del Estado n. 225, 19 de septiembre, pp. 73113-73118 [on line]. [Date accessed: 10 of November 2015]. Available from http://www.boe.es/diario_boe/txt. php?id=BOE-A-2013-9709

Moreno, J. L. (1934/1953). Who shall survive? Foundations of sociometry, group 
psychotherapy and sociodrama. New York: Beacon House. http: //www.asgpp.org/docs/WSS/WSS.html [publicado originalmente como Nervous and Mental Disease Monograph, 58, Washington, D. C., 1934]

National Association of Social Workers (NASW) and Association of Social Work Boards (ASWB) (2005). Standards for Technology and Social Work Practice [on line]. [Date accessed: 10 of November 2015] Available from http: //www.aswb. org/pdfs/TechnologySWPractice.pdf

Newman, M. E. J. (2010). Networks. An Introduction. Oxford: Oxford University Press. http://dx.doi.org/10.1093/acpro f:oso/9780199206650.001.0001

Ortiz, I. and Cummings, M. (2011). Global Inequality: Beyond the Bottom Billion. A Rapid Review of Income Distribution in 141 Countries. New York: United Nations Children's Fund (UNICEF). http:// dx.doi.org/10.2139/ssrn.1805046

Pakulski, J. and Waters, M. (1996). The reshaping and dissolution of social class in advanced society. Theory and Society, 25, 5, pp. 667-691. http://dx.doi. org/10.1007/BF00188101

Perry, C. L., Klepp, K. I., Halper, A., Hawkins, D. G. and Murray, D. M. (1986). A process evaluation study of peer leaders in health education. Journal of School Health, 56, pp. 62-67. http:// dx.doi.org/10.1111/j.17461561.1986. tb01176.x

Putnam, R. D. (1995). Bowling alone: America's declining social capital. Journal of Democracy, 6, pp. 65-78. http://dx.doi. org/10.1353/jod.1995.0002

Rogers, E. M. (1987). Progress, problems and prospects for network research: investigating relationships in the age of electronic communication technologies. Social Networks, 9, pp. 285-310.

Rogers, E. M. (2003). Diffusion of innovations. New York: FreePress. http://dx.doi. org/10.1016/03788733(87)900013

Schelling, T. (1978). Micromotives and macrobehavior. New York: Norton. http:// dx.doi.org/10.2307/2130499

Scott, J. (2011). Social Network Analysis. London: Sage. http://dx.doi. org/10.1007/s1327801000126

Simmel, G. (1971). On individuality and Social Forms. Chicago: University of Chicago.

Solomon, S., Weisbuch, G., de Arcangelis, L., Jan, N. and Stauffer, D. (2000). Physica, 277A, pp. 239-247. http://dx.doi. org/10.1016/S03784371(99)005439

Stauffer, D. and Aharony, A. (1991). Introduction to Percolation Theory. London: Taylor \& Francis. http://dx.doi. org/10.4324/9780203211595

Stiglitz, J. (2012). The Price of Inequality. New York: Norton. http://dx.doi. org/10.4337/ejeep.2013.01.11

Ellis, T. (2013). Joseph Stiglitz rings alarm bell over austerity [on line]. [Date accessed: 10 of November 2015] Available from http://www.ekathimerini.com/4dcgi/_w_articles_ wsite3_1_01/01/2013_476546

Valente, T. W. and Davis, R. L. (1999). Accelerating the diffusion of innovations using opinion leaders. Annals of the American Academy of Political and Social Sciences, 566, pp. 55-67. http://dx.doi. org/10.1177/0002716299566001005

Valente, T. W., Hoffman, B. R., Ritt-Olson, A., Lichtman, K. and Johnson, C. A. (2003).
The effects of a social network method for group assignment strategies on peer led tobacco prevention programs in schools. American Journal of Public Health, 93, pp. 1837-1843. http:// dx.doi.org/10.2105/AJPH.93.11.1837

Valente, T. W. and Pumpuang, P. (2007). Identifying opinion leaders to promote behavior change. Health Education and Behavior, 34, 6, pp. 881-896. http://dx.doi. org/10.1177/1090198106297855

Valente, T. W. (2010). Social Networks and Health: Models, Methods, and Applications. New York: Oxford University Press. http://dx.doi.org/10.1093/acpro f:oso/9780195301014.001.0001

Valente, T. W. (2012). Network Interventions. Science, 337, pp. 49-53. http:// dx.doi.org/10.1126/science.1217330

Villasante, T. (2006). Redes y conjuntos de acción: para aplicaciones estratégicas en los tiempos de la complejidad social. Redes- Revista hispana para el análisis de redes sociales, 11, 2, pp. 3-22.

Watts, D. J. (2007). A twenty-first century science. Nature, 445, p. 489. http:// dx.doi.org/10.1038/445489a

Weeden, K. A. and Grusky, D. B. (2012). The Three Worlds of Inequality. American Journal of Sociology, 117, 6, pp. 1723-1785. http://dx.doi. org/10.1086/665035

Zimmerman, M. A. (2000). Empowerment theory: Psychological, organizational, and community level of analysis. En E.J. Rappaport y E. Seidman (eds.) Handbook of community psychology, New York, Kluwer Academic, pp. 43-63. 